\title{
Excavation Analysis using Stress Path Dependent Soil Parameters
}

\author{
Hasbullah Nawir ${ }^{*}$, Bagus Eko Prasetyo ${ }^{2}$, Dayu Apoji3 ${ }^{*}$ \\ ${ }^{1}$ Associate Professor and Head of Soil Mechanics Laboratory, Faculty of Civil and Environmental Engineering, \\ Institut Teknologi Bandung, Indonesia. \\ ${ }^{2}$ Former Postgraduate Student, Geotechnical Engineering, Faculty of Civil and Environmental Engineering, Institut \\ Teknologi Bandung, Indonesia. \\ ${ }^{3}$ Research Associate, Soil Mechanics Laboratory, Faculty of Civil and Environmental Engineering, Institut Teknologi \\ Bandung, Indonesia. \\ *Corresponding author: hasbullah@si.itb.ac.id ; dayu.apoji@si.itb.ac.id
}

\begin{abstract}
This paper presents numerical analyses of an excavation using stress path dependent soil parameters, where soil elements in a region of the excavation are represented by specific soil parameters that correspond to their specific stress paths. The performance of the M1 excavation pit in Berlin sand was selected as the analysed case. This excavation pit was supported by diaphragm-wall with a single row of pre-stressed anchors. The numerical analyses of the excavation were performed using finite element program PLAXIS 3D. Mohr-Coulomb model and Hardening Soil model were used as the soil constitutive models. The analyses were performed using two approaches, which are: (i) analysis using axial compression soil parameters, and (ii) analysis using stress path dependent soil parameters. A set of conversion ratios were employed to convert the general soil parameters (i.e. axial compression stress path) to the soil parameters of the other stress paths. These conversion ratios were obtained from an experimental program of true triaxial tests conducted on Bangka sand. The comparison of the field records and the analysis results were discussed. The results show that the stress path dependent approach produced better prediction of diaphragm-wall deformation compare to the general approach using axial compression soil parameters.
\end{abstract}

Keywords_constitutive model, excavation, finite element analysis, soil parameter, stress path.

\section{INTRODUCTION}

$\mathrm{T}_{\mathrm{b}}$ he axial compression (AC) stress path has been regularly used in conventional triaxial tests to determine soil parameters for various geotechnical analyses [1]. However, this type of stress path may not be appropriate for all geotechnical cases [2], [3]. In unloading conditions (i.e. deep excavation with embedded earth retaining structures), the soil elements may encounter different stress paths, for instance, (i) axial extension (AE) at the base of excavation, (ii) lateral extension (LE) at the unexcavated region above the excavation base, and (iii) lateral compression (LC) at the unexcavated region below the excavation base, due to the lateral deformation of the embedded earth retaining structure. Consequently, soil elements in a region of an excavation should be represented by specific soil parameters that correspond to their stress paths [4].

This paper presents numerical analyses of an excavation using stress path dependent soil parameters. In this approach, soil elements in a region of an excavation are represented by specific soil parameters that correspond to their specific stress paths. The soil parameters for the other stress paths (i.e. AE, LC, LE) were determined based on their AC soil parameters by employing a set of conversion ratios [5]. Analysis using this approach was implemented to an excavation case in Berlin Sand [6]. The numerical analysis was performed using finite element program PLAXIS 3D. MohrCoulomb (MC) model and Hardening Soil (HS) model [7] were used as the soil constitutive models. Result of the analysis was then compared to the field records.

This study is intended to evaluate the proposed conversion ratios of soil parameters and to demonstrate an improved approach of excavation analysis, where more robust soil parameters are employed. It is expected that this study will contribute to the advancement of excavation analysis method, particularly since excavation and underground constructions have become essential parts of urban infrastructure development in densely populated cities in Indonesia.

\section{METHOD}

\section{A. $\quad$ Stress Path Dependent Soil Parameters}

The importance of stress path dependent soil parameters has been highlighted in numerous studies [2]-[4], [8], [9]. Nevertheless, obtaining the specific soil parameters of various stress path conditions is a problematic task since it is uncommon and impractical to apply various types of stress path (i.e. AE, LC, LE) in routine triaxial testing. Accordingly, the generic AC soil parameters are still regularly used in most of geotechnical analysis [10]. 
Table 1.

Conversion ratios of the stress path dependent soil parameters.

\begin{tabular}{ccccccccccc}
\hline \hline \multirow{2}{*}{ Stress Path } & \multicolumn{3}{c}{ Mohr Coulomb Model } & \multicolumn{5}{c}{ Hardening Soil Model } \\
& $\mathrm{c}^{\prime}$ & $\phi^{\prime}$ & $\mathrm{E}_{50}$ & $\psi$ & $\mathrm{c}^{\prime}$ & $\phi^{\prime}$ & $\mathrm{E}_{50}$ & $\mathrm{E}_{\text {oed }}$ & $\mathrm{E}_{\text {ur }}$ & $\psi^{\prime}$ \\
\hline AC & 1.00 & 1.00 & 1.00 & 1.00 & 1.00 & 1.00 & 1.00 & 1.00 & 1.00 & 1.00 \\
AE & 1.80 & 1.02 & 4.84 & 1.23 & 1.80 & 1.02 & 3.85 & 3.85 & 1.30 & 1.23 \\
LC & 2.64 & 1.08 & 1.74 & 1.54 & 1.08 & 1.57 & 1.74 & 1.74 & 1.33 & 1.54 \\
LE & 1.37 & 1.03 & 4.37 & 1.08 & 1.37 & 1.03 & 3.03 & 3.03 & 3.09 & 1.08 \\
\hline \hline
\end{tabular}

To tackle this issue, a set of conversion ratios has been proposed to determine the stress path dependent soil parameters [5]. The proposed conversion ratios are presented in Table 1. Using these ratios, the specific soil parameters of various stress paths (i.e. AE, LC, LE) can be simply determined based on their AC soil parameters, which are commonly interpreted in routine soil investigation program. These ratios were obtained from an experimental test program conducted on reconstituted Bangka sand. The experimental tests were performed using a stress controlled cubical true triaxial test apparatus developed in Institut Teknologi Bandung [11]. These ratios have been calibrated to the MC and HS model parameters.

\section{B Excavation Case}

The performance of M1 excavation pit in Berlin [6] was selected to be the analyzed case. The M1 pit is a deep excavation work conducted in the construction project of Verkehrsanlagen im Zentralen Bereich (VZB), a multimodal transportation line through the centre of Berlin. This excavation was supported by diaphragmwall with a single row of pre-stressed anchors. Figure 1 shows the M1 excavation pit which is located to the north of Lehrter Bahnhof station [12].

\section{(1) Geotechnical Conditions}

As described by Nikolinakou [6], the typical geotechnical profile at the M1 site consist of 3 to 4meter-thick of fill materials overlying sandy till materials. The sandy till materials can be further classified into three units, namely: (i) 6-meter-thick upper Holocene sands, (ii) 10-meter-thick glacial sands from the late Pleistocene, and (iii) 22-meter-thick glacial sands from the early Pleistocene. Thin layers of organic soils were also found in between the upper Holocene sands and the glacial sands. The engineering properties of these sands have been discussed by Borchert and Richter [13]. Based on this report, the suggested design friction angles $(\phi)$ of the Holocene sands, late Pleistocene, and early Pleistocene sands are $31^{\circ}, 34^{\circ}$, and $37^{\circ}$, respectively. The ground water table at the site was located approximately at 2 meters below the ground surface.

\section{(2) Earth Retaining Structures}

The M1 excavation pit was retained using a 1.2 to 1.5 meter-thick reinforced-concrete diaphragm-wall. The wall extended around the perimeter of the site, which was approximately 300 meters long and 25 meters wide. The wall was embedded to depths ranging from 25 to 31 meters. A single row of pre-stressed tieback anchors was installed to support the diaphragm-wall. Typically, each tieback was comprised of 8 to 9 strands of a grade 270 steel tendons. The anchors were installed at 2 to 3 meters below the ground surface, with a centre-to-centre space ranging between 1.0 and 1.5 meters. The anchors were grouted within the competent Pleistocene sands in a length of 8 meters.

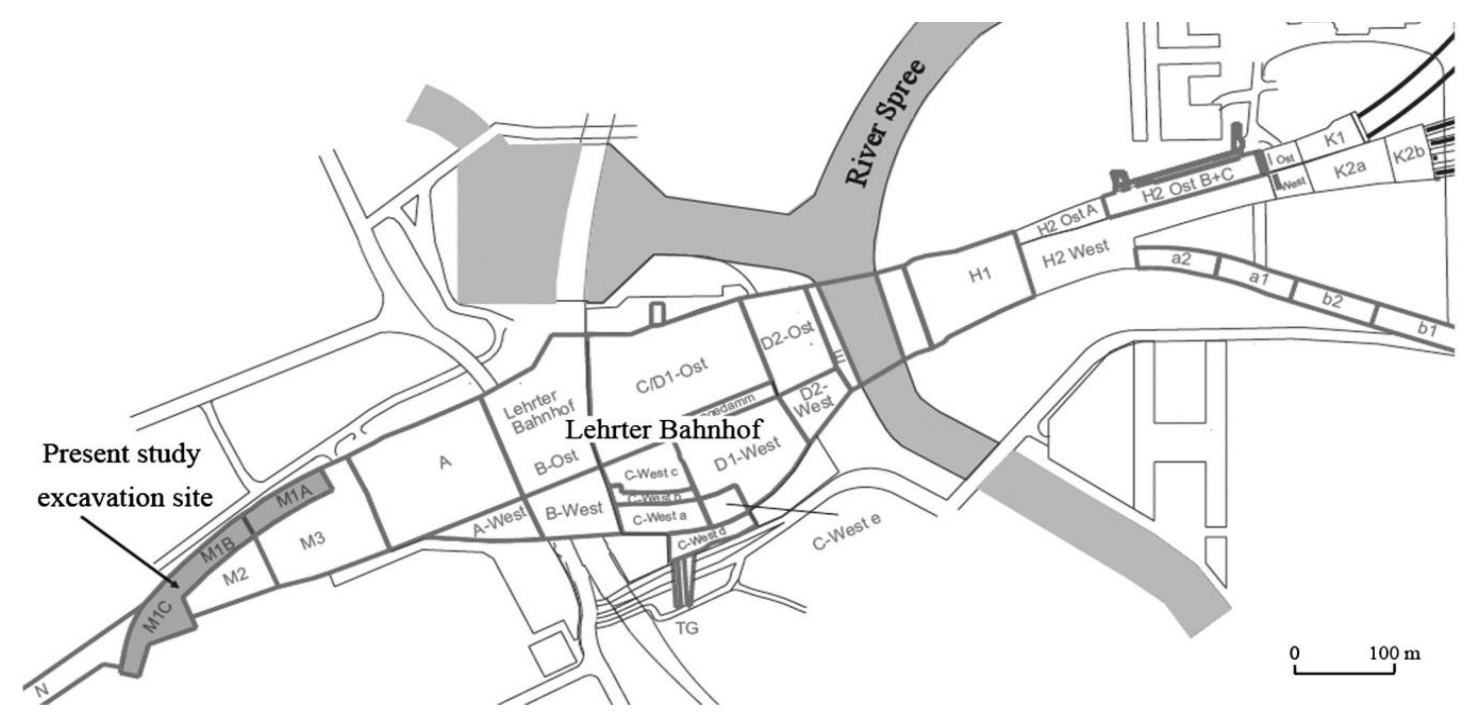

Figure 1. Plan view of the M1 excavation pit for VZB project in Berlin, taken from [6]. 
Table 2.

Geometry of the finite element model.

\begin{tabular}{cccccccc}
\hline \hline \multirow{2}{*}{ Location } & $\begin{array}{c}\text { Excavation depth } \\
(\mathrm{m})\end{array}$ & \multicolumn{2}{c}{ Diaphragm -wall } & \multicolumn{3}{c}{ Tieback Anchors } \\
\cline { 3 - 8 } & 22 & $\begin{array}{c}\text { Thick } \\
(\mathrm{m})\end{array}$ & $\begin{array}{c}\text { Depth } \\
(\mathrm{m})\end{array}$ & $\begin{array}{c}\text { Spacing } \\
(\mathrm{m})\end{array}$ & $\begin{array}{c}\text { Length } \\
(\mathrm{m})\end{array}$ & $\begin{array}{c}\text { Dip angle } \\
\left({ }^{\circ}\right)\end{array}$ & $\begin{array}{c}\text { Prestress } \\
\left(\mathrm{kN} / \mathrm{m}^{2}\right)\end{array}$ \\
\hline MQ3 & 1.5 & 28.7 & 1.0 & 34.5 & 35 & 540 \\
\hline \hline
\end{tabular}

Table 3.

Physical characteristics of Berlin sand and Bangka sand.

\begin{tabular}{lcc}
\hline \hline \multicolumn{1}{c}{ Physical Properties } & Berlin Sand $^{\mathrm{a}}$ & Bangka Sand $^{2}$ \\
\hline Spesific Gravity, $\mathrm{Gs}$ & 2.65 & 2.67 \\
Mean Particle, $\mathrm{d}_{50}(\mathrm{~mm})$ & 0.38 & 0.30 \\
Coefficient of Uniformity, $\mathrm{C}_{\mathrm{u}}$ & 3.00 & 2.33 \\
Coefficient of Curvature, $\mathrm{C}_{\mathrm{c}}$ & 1.20 & 0.92 \\
Maximum void ratio, $\mathrm{e}_{\max }$ & 0.590 & 0.851 \\
Minimum void ratio, $\mathrm{e}_{\min }$ & 0.201 & 0.709 \\
\hline \hline
\end{tabular}

${ }^{a}$ taken from [6]

The performance of the excavation was measured using monitoring devices, for instance, inclinometers and load cells. The inclinometers were installed within the diaphragm-wall to measure the wall deformation. The forces of the tieback anchors were measured using the load cells. Latterly, the uplift of the base slab was measured using the horizontal inclinometers.

\section{(3) Construction Sequences}

The construction of M1 pit was comprised of two main excavation stages. The first excavation was carried out after installation of the diaphragm-wall, to a depth of 2.5 meters below the initial ground surface. Secondly, an underwater excavation was carried out after the installation of the tieback anchors to a final formation elevation (i.e. in average 20.2 meters below the initial ground surface). Subsequently, a 1.5-meter-thick underwater concrete slab and a group of tension piles was casted at the base of excavation to enable dewatering of the pit. The underwater excavation method was selected due to high ground water table at the site and high permeability of the soil materials.

\section{Numerical Analysis}

\section{(1) Finite Element Model}

The finite element method (FEM) was employed to simulate the performance of the excavation. The threedimensional (3D) finite element analyses (FEA) of the M1 excavation pit were performed using commercial finite element program PLAXIS 3D. The analyses were performed on a section that corresponds to the location of inclinometers MQ3 (Figure 2). Since the excavation geometry was symmetrical, half-section model was considered in the analysis to minimize the computational cost. The soil profile was represented by borehole B1134, which located adjacent the MQ3. The soils were modelled using MC and HS models. The diaphragm-wall was modelled using elastic beam elements. The tieback anchors were modelled using node-to-node anchor element for the free anchor lengths, and geotextile element for the fixed anchor lengths. Summary of the excavation model geometry is presented Table 2 .

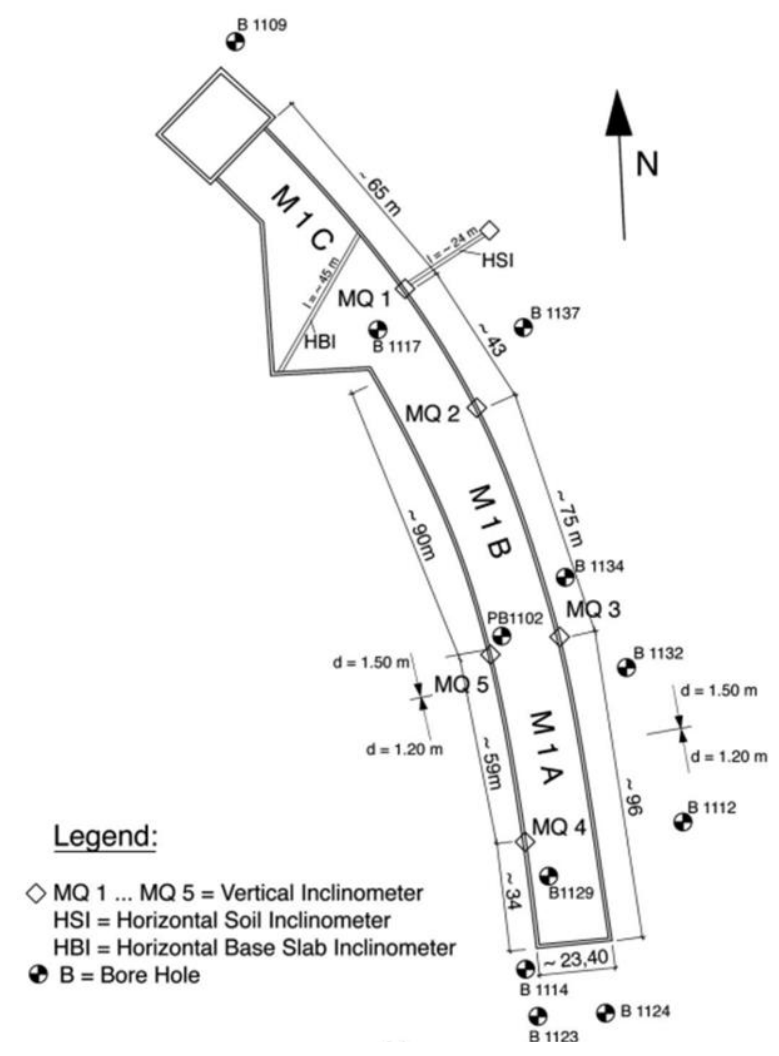

Figure 2. Plan view of the M1 excavation pit site conditions and the diaphragm-wall design, taken from [6].

The construction stages simulated in the analyses were comprised of (i) installation of the diaphragm-wall, (ii) first excavation to the depth of 2.5 meters below the initial ground surface, (iii) installation of the tieback anchors, and (iv) underwater excavation to the final formation elevation of 22 meters below the initial ground surface. Local changes in stresses or soil properties associated with the diaphragm-wall excavation and concreting were not considered in the analyses. The subsequent constructions of the anchor piles and base slab as well as the dewatering stage were also not considered in this study. 


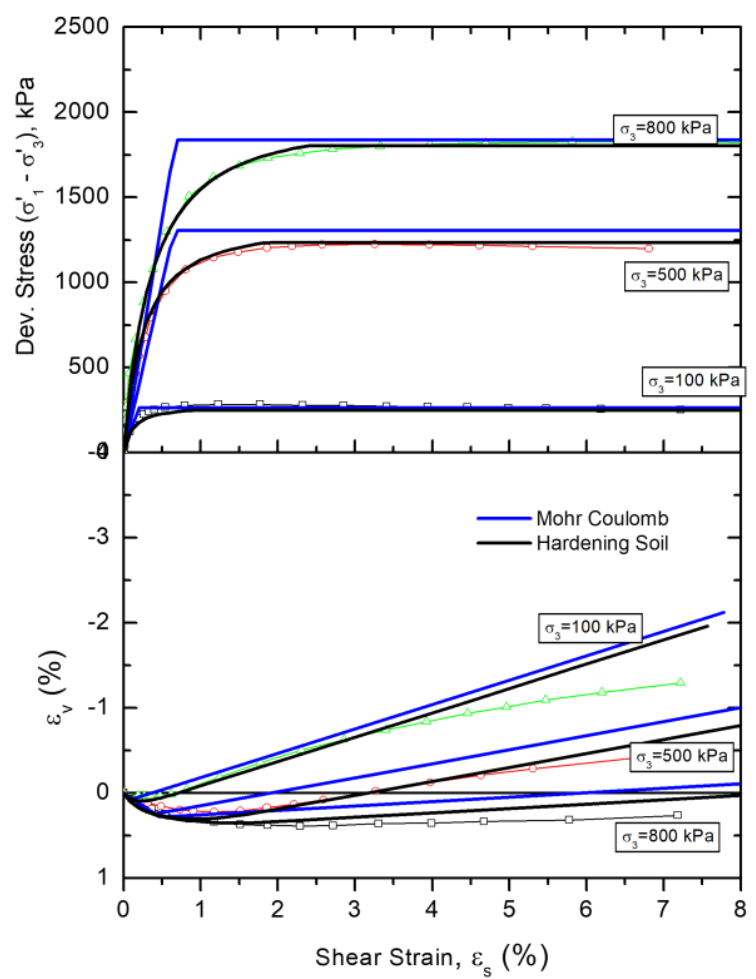

Figure 3. Typical triaxial test results of the Berlin sand and their numerical analyses using HS and MC models, triaxial test data taken from [6].

\section{(2) Soil Properties and Model Parameters}

Table 3Error! Reference source not found. presents the physical properties of Berlin sands [6], with comparison to the physical properties of Bangka sands [5]. It is important to note that the conversion ratios used in this study (i.e. in the case of Berlin sand) were obtained based on a program of experimental tests conducted on Bangka sand. The properties of the Berlin sands were determined from a laboratory test program, which was conducted on reconstituted specimens [14], [15]. As can be seen in the table, both Bangka sand and Berlin sand have similar values of specific gravity (Gs), and relatively comparable values of mean particle $\left(\mathrm{d}_{50}\right)$, coefficient of uniformity $\left(\mathrm{C}_{\mathrm{u}}\right)$, and coefficient of curvature $\left(\mathrm{C}_{\mathrm{c}}\right)$. However, it can be observed that the Bangka sands exhibit higher values of the maximum and minimum void ratios.

Typical triaxial test results of the Berlin sand (i.e. with void ratio of approximately 0.51 ) at different confining pressures are shown in Figure 3. Numerical analyses have been performed on these results to validate the soil parameters. Secant modulus $\left(\mathrm{E}_{50}\right)$ of the specimens with confining pressure of 100,500 , and $800 \mathrm{kN} / \mathrm{m}^{2}$ were found to be 140,200 , and $275 \mathrm{MN} / \mathrm{m}^{2}$, respectively. It can be observed that the MC model could capture the general strain behaviour of the Berlin sand. However, having bi-linear elastic-plastic formulation, this model was not able to capture the soil non-linearity. In contrast,

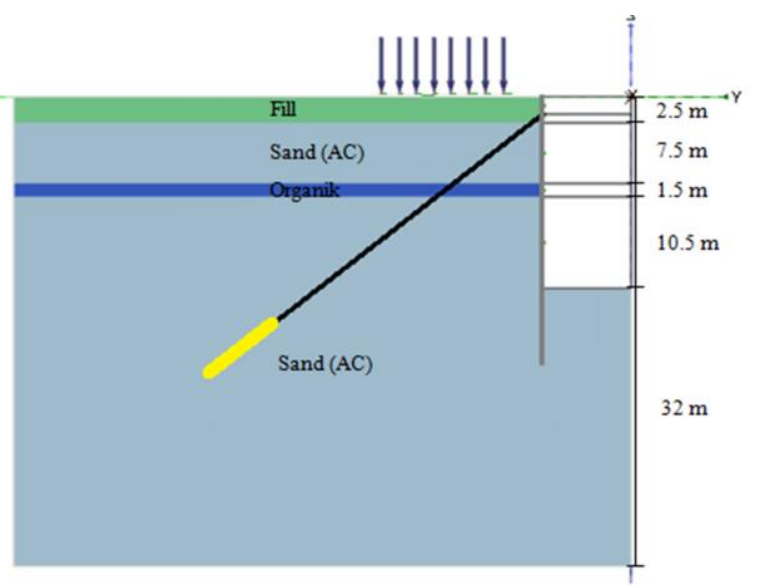

(a)

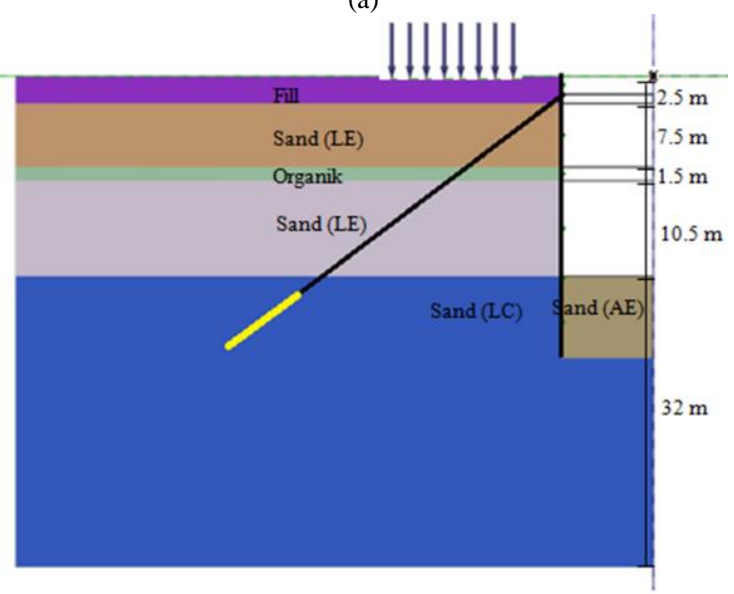

(b)

Figure 4. Finite element model of the excavation using: (a) AC soil parameters, and (b) stress path dependent soil

the HS model could simulate the non-linear behaviour of the sand, even at their small strain levels. An equivalent value of friction angle of $\phi^{\prime}=33^{\circ}$ was used in the analysis. As expected, it can be observed that the higher confining pressure will produce the higher failure stress.

\section{(3) Analysis Approach}

The excavation analysis was performed using two approaches, which are: (i) analysis using general AC soil parameters, and (ii) analysis using stress path dependent soil parameters. The approaches are described below.

\section{Approach 1: Analysis using general AC Soil Parameters}

The first analysis can be considered as a regular excavation analysis. In this approach, the numerical analysis of the excavation was conducted using the AC soil parameters. Figure 4(a) shows the finite element model of the excavation of the first analysis approach. In this model, the sand was only classified into 2 units, namely, (i) the upper sand layer, and (ii) the lower (i.e. more competent) sand layer. The AC soil parameters were selected as the input of both the sand layers. A thin organic layer was presence in between the sand layers. 


\section{Approach 2: Analysis using Stress Path Dependent Soil Parameters}

Stress path dependent soil parameters were used in the second analysis. In contrast to the previous approach, soil elements in each region of the excavation model were represented by specific soil parameters that correspond to their specific stress paths. Figure 4(b) shows the finite element model of the excavation of the second analysis approach. The sand was divided several regions, namely, (i) the upper sand layer which encountered LE stress path, (ii) the lower (i.e. more competent) sand layer which also encountered LE stress path, (iii) the sand layer at the unexcavated region below the excavation base, which encountered LC due to the lateral deformation of the embedded earth retaining structure, and (iv) the AE sand at the base of excavation.

\section{RESULTS AND DISCUSION}

Figure 5(a) and Figure 5(b) show the typical vertical and horizontal deformation patterns produced by the analyses. In general, both analyses produced comparable deformation patterns. Figure 5(a) shows that ground settlement occurred at the unexcavated ground surface. In contrast, uplift heaving occurred at the base of the excavation. Figure 5(b) shows the lateral deformation due to the excavation. It can be observed that the lateral soil movement occurred behind the diaphragm-wall toward the excavated region. Higher magnitude of the lateral soil deformation was occurred at about 4 to 20 meters below the initial ground surface. This pattern is sensible since there were lateral supports on the wall at elevation 2.5 meters (tieback anchors) and at the base of excavation. These deformation patterns confirm the stress paths assumed for each soil regions in the second analysis approach.

Figure 6 shows the details deflection magnitude of the diaphragm-wall along the depth. This figure compares the field record (i.e. inclinometer MQ3) and the results of the numerical analyses. Five numerical simulation results are presented in this figure, that are: (i) MC model using general AC approach (ii) HS model using general AC approach (iii) MC model using stress dependent approach (iv) HS model using stress dependent approach and (vi) advanced MIT-E3 model [16] based on study by Nikolinakou [6]. The results were encouraging. As expected, the models using stress dependent approach produced the closest predictions to the field record, where the more advance model of HS produced better prediction than the MC model. On the other hand, the general AC approach (i.e. both MC and HS models) significantly overestimated the field record. These imply that the current practice (i.e. excavation analysis using AC soil parameters) can be considered in more conservative side. Even though the current practice appears to provide more safety margin to the designer, the proposed stress dependent approach can be projected to produce more accurate deflection magnitudes. It is interesting to note that the most advance soil model (i.e. MIT-E3) underestimated the actual wall deflection.

These results show that the proposed stress dependent approach might be a promising method to produce a more reliable and accurate method of excavations.

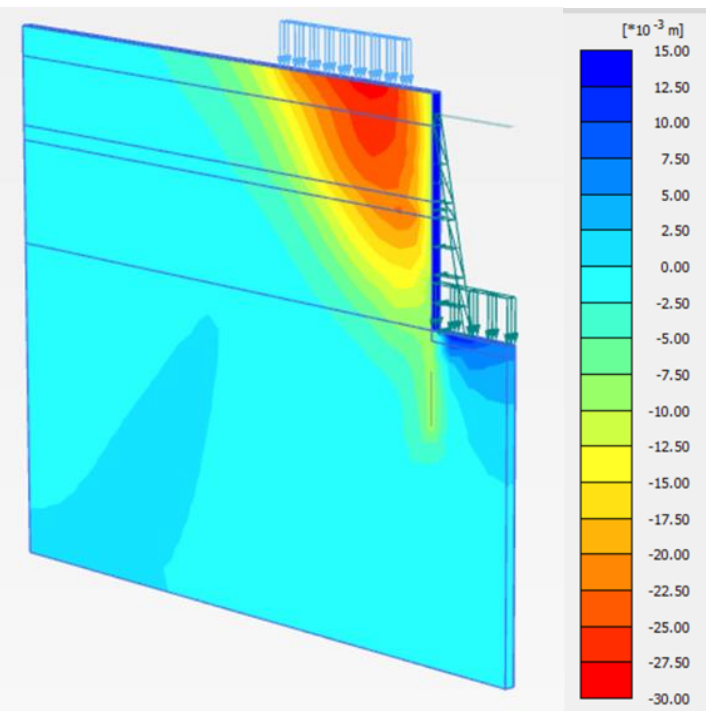

(a)

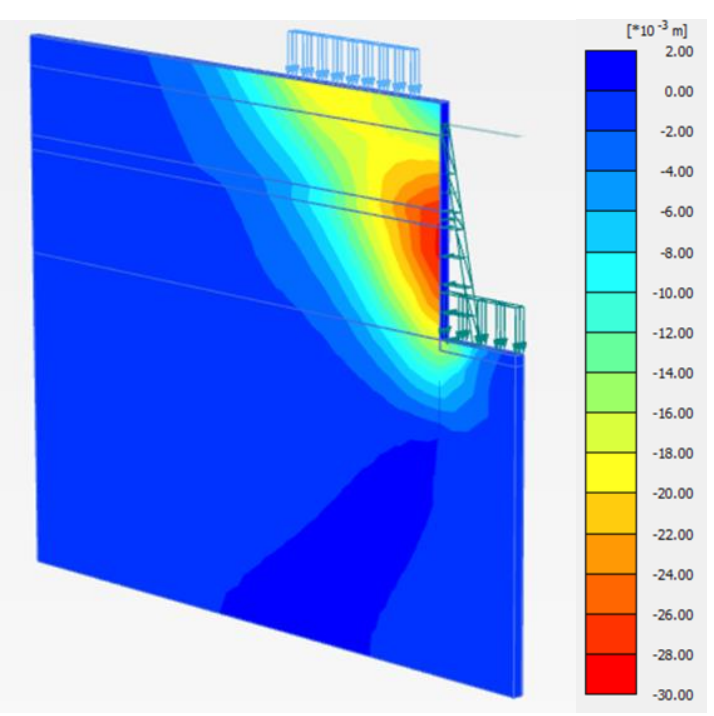

(b)

Figure 5. Typical pattern of ground deformation: (a) vertical, and (b) horizontal.

However, several notes need to be taken for further studies. Firstly, the conversion ratios were obtained from only an experimental test program using Bangka sand as the sample. Therefore, further investigations would be required to validate and improve these ratios, especially using various soil samples. Lastly, more case study analyses should be taken to further validate and confirm the applicability of the proposed approach.

\section{CONCLUSION}

Numerical analyses of an excavation in Berlin sand have been performed. The analyses were conducted on the M1 excavation pit using two different approach, for instance, (i) analysis using general AC soil parameters, and (ii) analysis using stress path dependent soil parameters. The comparison of the field records and the analysis results has been discussed.

The results show that, compare to the general approach using AC soil parameters, the models using stress dependent approach produced the closest predictions to the field record. Therefore, it can be concluded that the 


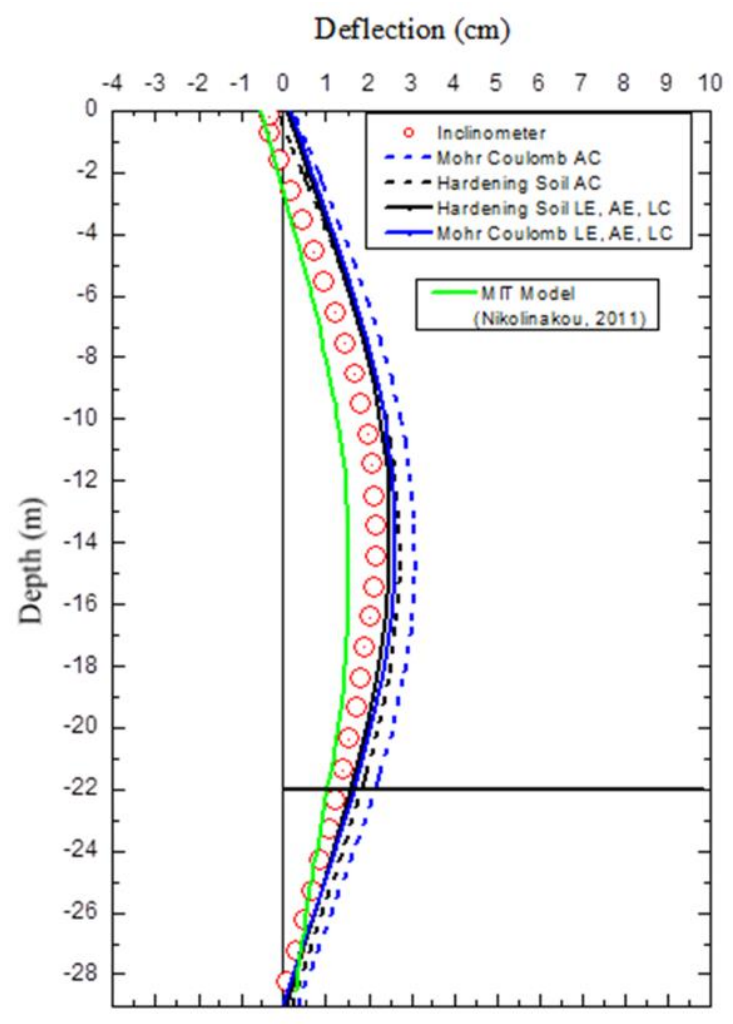

Figure 6. Deflection of the diaphragm-wall: inclinometer and numerical simulations

proposed stress dependent approach might be a promising method to produce a more reliable and accurate method of excavations. Nevertheless, further investigations would be required to validate these ratios, especially using various soil samples. More case study analyses should also be taken to confirm the applicability of the proposed approach.

\section{REFERENCES}

[1] P. V. Lade, Triaxial Testing of Soils. John Wiley \& Sons, 2016.

[2] T. W. Lambe and W. A. Marr, "Stress Path Method: Second Edition," J. Geotech. Geoenvironmental Eng., vol. 105, no. GT6, Jun. 1979.

[3] W. T. Lambe, "Stress Path Method," J. Soil Mech. Found. Div., vol. 93, no. 6, pp. 309-331, 1967.

[4] C. W. W. Ng, "Stress Paths in Relation to Deep Excavations," J. Geotech. Geoenvironmental Eng., vol. 125, no. 5, pp. 357-363, May 1999.

[5] B. E. Prasetyo, "Studi pengaruh lintasan tegangan hasil uji true triaxial tanah pasir pada analisis galian dalam menggunakan metode elemen hingga," Tesis (Magister Teknik Sipil), Institut Teknologi Bandung, Bandung, 2015.

[6] M. A. Nikolinakou, A. J. Whittle, S. Savidis, and U. Schran, "Prediction and Interpretation of the Performance of a Deep Excavation in Berlin Sand," J. Geotech. Geoenvironmental Eng., vol. 137, no. 11, pp. 1047-1061, Nov. 2011.

[7] T. Schanz, P. A. Vermeer, and P. G. Bonnier, "The hardening soil model: formulation and verification," 2000 Comput. Geotech., pp. 281296, 1999.

[8] Y. M. A. Hashash and A. J. Whittle, "Ground Movement Prediction for Deep Excavations in Soft Clay," J. Geotech. Eng., vol. 122, no. 6, pp. 474-486, Jun. 1996.

[9] C. W. Ng, E. H. Leung, and C. K. Lau, "Inherent anisotropic stiffness of weathered geomaterial and its influence on ground deformations around deep excavations," Can. Geotech. J., vol. 41, no. 1, pp. 12-24, Feb. 2004.

[10] R. B. J. Brinkgreve, "Selection of Soil Models and Parameters for Geotechnical Engineering Application," 2005, pp. 69-98.

[11] M. E. M. Lumbantoruan, "Pengembangan true triaxial cell dan penggunaannya dalam studi perilaku respon tegangan dan regangan tanah tropikal di Bandung," Tesis (Magister Teknik Sipil), Institut Teknologi Bandung, Bandung, 2013.

[12] K.-D. Mönnich and J. Erdmann, "Planning new public transportation in Berlin," Struct. Eng. Int., vol. 7, no. 4, pp. 231-232, 1997.

[13] K. M. Borchert and T. Richter, "Gutachterliche Beurteilung zum Ansatz der Bodensteifigkeiten beim Bauvorhaben VZB-Berlin.," GuD Consult, Berlin, 1994.

[14] T. Becker, "Triaxialversuche mit reduzierter Endflächenreibung zur Untersuchung des Materialverhaltens von Berliner Sand," Diplomarbeit am Fachgebiet Grundbau und Bodenmechanik der Technischen Universität Berlin, 2002.

[15] R. Glasenapp, "Triaxialversuche mit Berliner Sand," Diplomarbeit am Fachgebiet Grundbau und Bodenmechanik der Technischen Universität Berlin, 2002.

[16] A. J. Whittle and M. J. Kavvadas, "Formulation of MIT-E3 Constitutive Model for Overconsolidated Clays," J. Geotech. Eng., vol. 120, no. 1, pp. 173 198, Jan. 1994. 